\title{
Analisis Pengelompokan Peraturan Kementerian dengan Menggunakan K-Means Clustering
}

\author{
Resistania Anggita Putri ${ }^{[1]}$, Nida Inayah Maghfirani ${ }^{[2]}$, Galih Rendi Setyawan ${ }^{[3]}$, Adam Achmad Rayhan ${ }^{[4]}$, Nur Aini \\ Rakhmawati $^{[5]}$ \\ Department Information System [1], [2], [3], [4], [5] \\ Fakultas Teknologi Elektro dan Informatika Cerdas \\ Institut Teknologi Sepuluh Nopember, Surabaya, Indonesia \\ resistania@gmail.com ${ }^{[1]}$, inayahmaghfirani@gmail.com ${ }^{[2]}$, rendis1408@gmail.com ${ }^{[3]}$, adamarayhan@gmail.com ${ }^{[4]}$, \\ nur.aini@is.its.ac.id ${ }^{[5]}$
}

\begin{abstract}
Thousands Ministry Regulations are found in Indonesia shows that it is a big number. These regulations are intended to focus on various fields in order to be upheld in the public interest. It has recently been discovered that the numbers are increasing and some are no longer enforced. Clustering in data mining can be used to find out the focus of problems are often discussed at each ministry. The method that will be used for clustering ministry regulation data is the $\mathrm{K}$-Means algorithm. $\mathrm{K}$ Means is a non-hierarchical data clustering method partitions data into clusters so data that has the same characteristics will be grouped into one cluster and data that has different characteristics will be grouped into another cluster. This research was conducted by conducting data collection, data cleaning, data processing, and visualization of the results. The results of this paper are grouping the best ministerial regulations into four clusters that have an inertia value of 405.142786991133 . Cluster 0 is a collection of regulations on the empowerment of children, women, and victims of violence. Cluster 1 is a collection of regulations on environmental policies in both flora and fauna. Cluster 2 is a collection of regulations relating to science and professionalism. Cluster 3 is a collection of regulations relating to the safety of the creative economy in the field of tourism.
\end{abstract}

Keywords-Clustering, K-Means, Regulations, Ministry

\begin{abstract}
Abstrak - Ribuan Peraturan Kementerian yang ditemukan di Indonesia menunjukkan bahwa jumlahnya besar. Peraturanperaturan yang dibuat ini ditujukan untuk beragam bidang agar dapat ditegakkan demi kepentingan umum. Baru-baru ini telah ditemukan bahwa jumlahnya semakin meningkat dan beberapa sudah tidak lagi ditegakkan. Clustering dalam data mining dapat digunakan untuk mengetahui fokus permasalahan apa yang sering dibahas pada setiap kementerian. Metode yang akan dipakai untuk clustering data peraturan-peraturan kementerian adalah algoritma K-Means. K-Means merupakan metode data clustering non hirarki yang mempartisi data ke dalam cluster sehingga data yang mempunyai karakteristik yang sama akan dikelompokkan ke dalam satu cluster, sedangkan data yang mempunyai karakteristik yang berbeda akan dikelompokkan ke dalam cluster lain. Penelitian ini dilakukan dengan melakukan tahap pengambilan data, pembersihan data, pemrosesan data, dan visualisasi hasil. Hasil dari penelitian ini adalah pengelompokan Peraturan Kementerian terbaik menjadi empat
\end{abstract}

cluster yang memiliki nilai inertia 405.142786991133. Cluster 0 adalah kumpulan peraturan tentang pemberdayaan anak, perempuan, dan korban kekerasan. Cluster 1 adalah kumpulan peraturan tentang kebijakan lingkungan baik flora dan fauna. Cluster 2 adalah kumpulan peraturan yang berkaitan dengan keilmuan dan keprofesian. Cluster 3 adalah kumpulan peraturan yang berkaitan dengan keselamatan ekonomi kreatif di bidang pariwisata.

\section{Kata Kunci-Clustering, K-Means, Peraturan, Kementerian}

\section{PENDAHULUAN}

Dalam kehidupan ini terdapat kebebasan yang diberikan kepada setiap individu. Bagaimana kebebasan tersebut tidak merugikan satu sama lain dan saling menguntungkan adalah dengan memberikan peraturan. Peraturan merupakan sebuah perangkat yang sudah disepakati bersama yang digunakan sebagai pedoman kehidupan dengan tujuan untuk menciptakan ketertiban, keteraturan, dan ketenteraman [1]. Menurut Undang - Undang Dasar 1945 Pasal 1 ayat (3), Indonesia merupakan negara hukum. Di Indonesia, peraturan sangat dibutuhkan untuk memberikan pedoman bagi masyarakat dan pemerintahannya. Dalam menjalankan pemerintahan, terdapat beberapa instansi yang mengeluarkan peraturan sesuai dengan bidangnya masing-masing.

Berdasarkan Undang-Undang Republik Indonesia Nomor 39 Tahun 2008 tentang Kementerian Negara, kementerian adalah perangkat pemerintah yang membidangi urusan tertentu dalam pemerintahan. Dalam menjalankan tugasnya, kementerian pasti memiliki peraturan. Peraturan Kementerian merupakan peraturan yang dikeluarkan oleh kementeriankementerian negara masing-masing dengan tujuan mengatur sesuatu hal (Regeling) dan melakukan pengangkatanpengangkatan (Beschikking) [2].

Peraturan perundang-undangan yang telah dibuat tentunya harus ditunjukkan kepada masyarakat bahwa peraturan tersebut ada yaitu dengan didokumentasikan oleh Jaringan Dokumentasi Dan Informasi Hukum Nasional atau disingkat dengan JDIHN. Adapun JDIHN merupakan wadah pendayagunaan bersama atas dokumen hukum secara tertib, 
terpadu, dan berkesinambungan, serta merupakan sarana pemberian pelayanan informasi hukum secara lengkap, akurat, mudah, dan cepat sesuai dengan Pasal 1 ayat 1 Peraturan Presiden Nomor 33 Tahun 2012.

Dalam pembuatannya, Peraturan Kementerian berfokus pada beberapa permasalahan, di mana permasalahan tersebut menunjukkan bagaimana kondisi di Indonesia yang telah atau sedang terjadi. Seperti contohnya, perubahan ketiga UUD 1945 yang bertujuan untuk menyempurnakan aturan dasar serta mengakomodasi perkembangan kondisi bangsa dan permasalahan zaman [3]. Untuk mengetahui kondisi dan permasalahan apa yang sering dibahas maka akan dilakukan pengelompokan Peraturan Kementerian dengan menggunakan analisis clustering.

Analisis clustering merupakan bentuk analisis statistika yang bertujuan untuk mengelompokkan objek-objek berdasarkan kesamaan karakteristik yang ada di objek tersebut [4]. Di beberapa literatur, analisis clustering dikategorikan berdasar kriteria masing-masing seperti tipe dari data masukan, hingga strategi clustering [5]. Banyak metode untuk melakukan analisis cluster, salah satunya adalah $K$-Means. $K$ Means merupakan metode clustering yang populer dan sering digunakan. K-Means Clustering adalah metode cluster data mining menggunakan descriptive model untuk menjelaskan algoritma pengelompokan objek dengan karakteristik yang sama. Metode ini bekerja untuk mengurangi variasi antar data yang ada pada satu cluster dan memaksimalkan variasi pada cluster lainnya [6]. Kekurangan yang dimiliki oleh metode $K$ Means Clustering salah satunya adalah tidak adanya ketentuan berapa jumlah partisi cluster yang terbaik, sedangkan penentuan jumlah partisi yang berbeda bisa menghasilkan keanggotaan cluster yang berbeda [7].

Analisis yang dilakukan bertujuan untuk mengetahui pengelompokan data Peraturan Kementerian melalui teknik data mining, di mana pengolahan data menggunakan algoritma K-Means Clustering. Peraturan Kementerian yang digunakan akan diambil melalui website JDIH Kementerian. Output yang dihasilkan adalah kata-kata pada Peraturan Kementerian yang memiliki karakteristik yang sama. Output tersebut dapat digunakan untuk mengetahui permasalahan apa saja yang banyak menjadi fokus dari Peraturan Kementerian.

Penelitian ini diharapkan bisa memberikan wawasan tentang fokus permasalahan apa yang sering dibahas dalam Peraturan Kementerian dengan pengelompokan Peraturan Kementerian dengan metode $K$-Means Clustering .

\section{METODOLOGI}

Penelitian ini mengacu pada metode KDD (Knowledge Discovery In Database) yang merupakan metode yang mengacu pada identifikasi informasi yang valid dan baru yang ada dalam database. Metode ini biasa digunakan untuk menyelesaikan klasifikasi data dan pengelompokan data [8]. Gambar 1 menunjukkan tahap-tahap pada metode KDD.

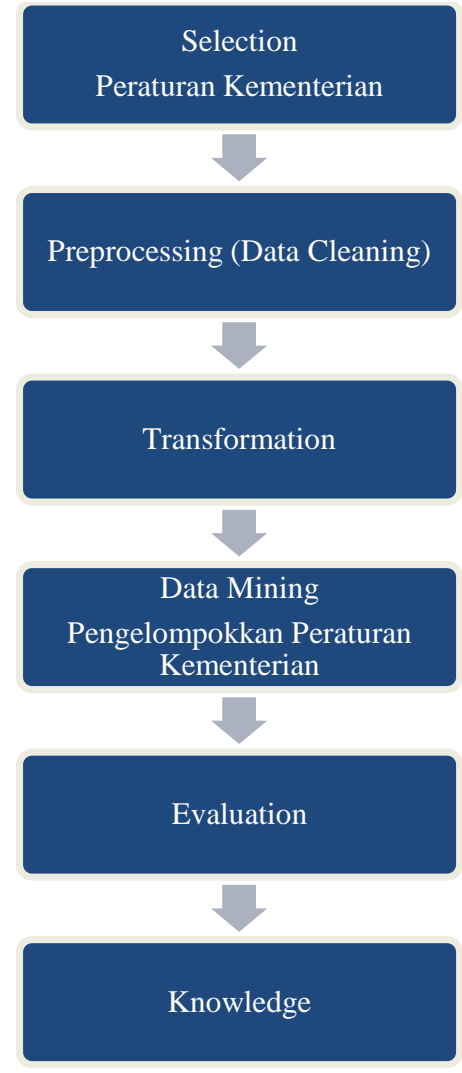

Gambar. 1. Metode Knowledge Discovery In Database

Pada tahap Preprocessing hingga Knowledge hingga terakhir melihat pada kode metode $K$-Means Clustering yang digunakan [9]. Berikut merupakan tahapan dari KDD untuk penelitian ini :

\section{1) Selection}

Tahap ini bertujuan untuk mengambil atau memilih Peraturan Kementerian yang akan digunakan. Pada tahap ini pengambilan data dilakukan dengan web mining pada situssitus website resmi setiap kementerian. Dari masing-masing situs tersebut dilakukan pengambilan seluruh peraturan yang ada di situs tersebut. Pengambilan dilakukan dengan menggunakan aplikasi web scraping yaitu ParseHub. Tabel 1 menunjukkan situs Peraturan Kementerian yang digunakan :

TABLE I. SITUS PERATURAN KEMENTERIAN YANG DIGUNAKAN

\begin{tabular}{|l|l|l|}
\hline No & \multicolumn{1}{|c|}{ Kementerian } & \multicolumn{1}{c|}{ Situs Web } \\
\hline 1 & $\begin{array}{l}\text { Kementerian Pemberdayaan } \\
\text { Perempuan dan Perlindungan Anak }\end{array}$ & jdih.kemenpppa.go.id \\
\hline 2 & Kementerian Riset dan Teknologi & jdih.ristekdikti.go.id \\
\hline 3 & $\begin{array}{l}\text { Kementerian Lingkungan Hidup } \\
\text { dan Kehutanan }\end{array}$ & jdih.menlhk.co.id \\
\hline 4 & Kementerian Pertanian & jdih.pertanian.go.id \\
\hline 5 & Kementerian Pariwisata & jdih.kemenpar.go.id \\
\hline
\end{tabular}

Pada Gambar 2 menunjukkan tampilan aplikasi ParseHub yang digunakan untuk mengambil data Peraturan Kementerian pada situs yang ada. 
Hasil pengambilan data akan disimpan sebagai CSV dan dapat diakses di Zenodo [10]. Gambar 3 merupakan beberapa data yang telah disimpan sebagai csv. Dan untuk data lengkap yang digunakan pada penelitian ini bisa diakses pada Zenodo.

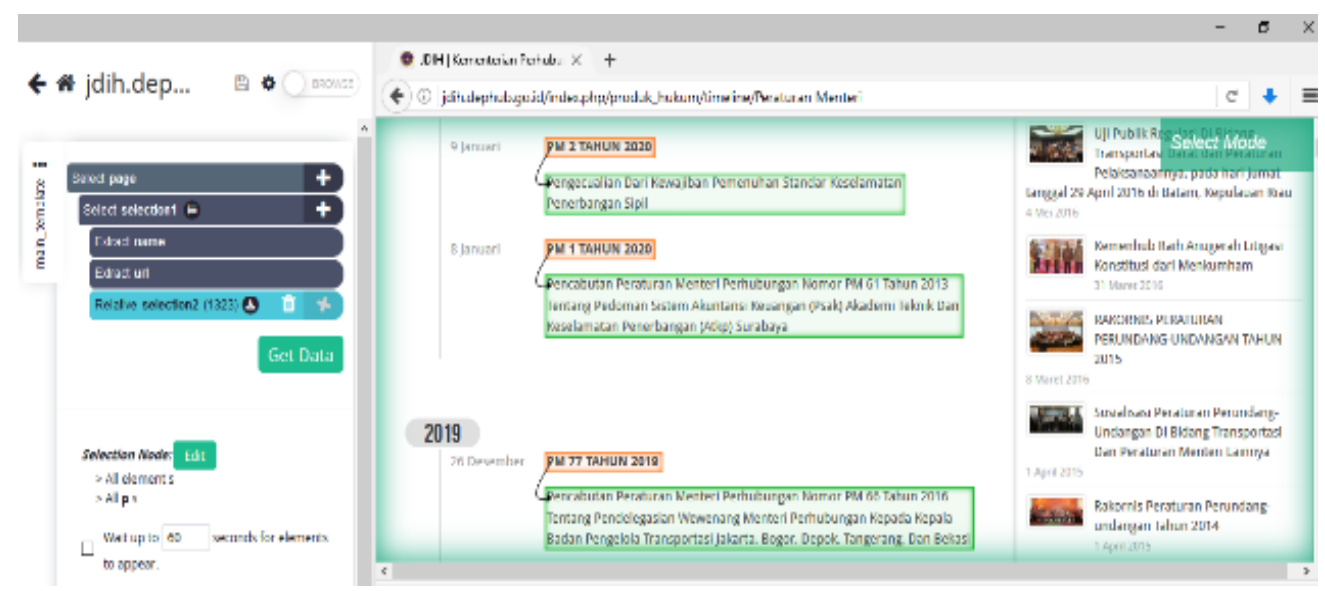

Gambar. 2. proses crawling menggunakan aplikasi ParseHub

182/M/KPT/2019,181/M/KPT/2019,180/M/KPT/2019,142/M/KPT/2019,140/M/KPT/2019,136/M/KPT/2019,135/M/KPT/2019,134/M/KPT/2019,133/M/KPT/2019,132/M/KPT/2019 ,131/M/KPT/2019,130/M/KPT/2019,129/M/KPT/2019,128/M/KPT/2019,127/M/KPT/2019,126/M/KPT/2019, 125/M/KPT/2019,124/M/KPT/2019,115/M/KPT/2019,114/M/KPT/201 $9,113 /$ M/KPT/2019,112/M/KPT/2019,111/M/KPT/2019,110/M/KPT/2019,109/M/KPT/2019,101/M/KPT/2019, 98/M/KPT/2019, 97/M/KPT/2019, 96/M/KPT/2019, 95/M/KPT/2019, 9 4/M/KPT/2019,93/M/KPT/2019,92/M/KPT/2019, 91/M/KPT/2019, 90/M/KPT/2019, 89/M/KPT/2019, 88/M/KPT/2019, 87/M/KPT/2019, 86/M/KPT/2019, 85/M/KPT/2019, 84/M/KPT/2 $019,83 /$ M/KPT/2019, 82/M/KPT/2019, 81/M/KPT/2019, 80/M/KPT/2019, 79/M/KPT/2019, 78/M/KPT/2019, 77/M/KPT/2019, 76/M/KPT/2019, 75/M/KPT/2019, 74/M/KPT/2019, 73/M/ KPT/2019,70/M/KPT/2019,69/M/KPT/2019,68/M/KPT/2019,67/M/KPT/2019, 66/M/KPT/2019,65/M/KPT/2019, 64/M/KPT/2019, 63/M/KPT/2019, 62/M/KPT/2019, 61/M/KPT/2019, 60/M/KPT/2019,59/M/KPT/2019,49/M/KPT/2019,45/M/KPT/2019,44/M/KPT/2019,43/M/KPT/2019, 42/M/KPT/2019, 41/M/KPT/2019,40/M/KPT/2019

Pencabutan Izin Pendirian Akademi/Politeknik Jawa Dwipa Semarang di Kabupaten Semarang dan Izin Pembukaan Program Studi pada Akademi/Politeknik Jawa Dwipa Semarang di Kabupaten Semarang yang Diselenggarakan oleh Yayasan Tri Sasongko, Pencabutan Izin Pendirian Politeknik Surakarta di Kota Surakarta dan Izin Pembukaan Program Studi pada Politeknik Surakarta di Kota Surakarta yang Diselenggarakan oleh Yayasan Institut Pengembangan Kewirausahaan Dan Kejuruan Indonesia, Pencabutan Izin Pendirian Akademi Manajemen Industri Surakarta di Kota Surakarta dan Izin Pembukaan Program Studi pada Akademi Manajemen Industri Surakarta di Kota Surakarta, "INDIKATOR KINERJA UTAMA PERGURUAN TINGGI NEGERI DAN LEMBAGA LAYANAN PENDIDIKAN TINGGI DI LINGKUNGAN KEMENTERIAN RISET, TEKNOLOGI, DAN PENDIDIKAN TINGGI TAHUN 2019", FORMULA ALOKASI DAN PENGGUNAAN BANTUAN OPERASIONAL PERGURUAN TINGGI NEGERI NONPENELITIAN, Pencabutan Izin Pendirian Sekolah Tinggi Ilmu Teknik "Widya Dharma" di Kota Surabaya dan Izin Pembukaan Program Studi pada Sekolah Tinggi Ilmu Teknik "Widya Dharma” di Kota Surabaya yang Diselenggarakan oleh Yayasan Pendidikan Wonokromo, Pencabutan Izin Pendirian Akademi Peternakan PGRI Jember di Kabupaten Jember dan Izin Pembukaan Program Studi pada Akademi Peternakan PGRI Jember di Kabupaten Jember yang Diselenggarakan oleh Yayasan PLPT-PGRI, Pencabutan Izin Pendirian Akademi Kebidanan Permata Delima Mojokerto di Kabupaten Mojokerto dan Pembukaan Program Studi pada Akademi Kebidanan Permata Delima Mojokerto di Kabupaten Mojokerto yang diselenggarakan oleh Yayasan Pendidikan Permata Delima Mojokerto, Pencabutan Izin Pendirian Sekolah Tinggi Keguruan dan Ilmu Pendidikan Tri Buwana dan Izin Pembukaan Program Studi pada Sekolah Tinggi Keguruan dan Ilmu Pendidikan Tri Buwana di Kota Surabaya yang Diselenggarakan oleh Yayasan Pendidikan Pembangunan Surabaya, Pencabutan Izin Pendirian Sekolah Tinggi Teknologi Budi Utomo di Malang dan Izin Pembukaan Program Studi pada Sekolah Tinggi Teknologi Budi Utomo di Malang yang Diselenggarakan oleh Yayasan Masjid Khodijah Malang, Pencabutan Izin Pendirian Sekolah Tinggi Ilmu Ekonomi "Pariwisata Satya Widya" Surabaya di Kota Surabaya dan Izin Pembukaan Program Studi pada Sekolah Tinggi Ilmu Ekonomi "Pariwisata Satya Widya" Surabaya di Kota Surabaya yang Diselenggarakan oleh Yayasan Satya Widya Surabaya,Pencabutan Izin Pendirian Akademi Pariwisata Bhakti Wiyata di Kediri dan Izin Pembukaan Program Studi pada Akademi Pariwisata Bhakti Wiyata di Kediri yang Diselenggarakan oleh Yayasan Bhakti Wiyata, Pencabutan Izin Pendirian Akademi Teknik Nasional Sidoarjo di Kabupaten Sidoarjo dan Izin Pembukaan Program Studi pada Akademi Teknik Nasional Sidoarjo di Kabupaten Sidoarjo yang Diselenggarakan oleh Yayasan Teknik Nasional,Pencabutan Izin Pendirian Akademi Teknologi Industri Tekstil Surabaya di Kota Surabaya dan Izin Pembukaan Program Studi pada Akademi Teknologi Industri Tekstil Surabaya di Kota Surabaya yang Diselenggarakan oleh Yayasan Tekstil Surabaya,Pencabutan Izin Pendirian Akademi Manajemen Informatika dan Komputer Aji Jaya Baya di Kediri dan Izin Pembukaan Program Studi pada Akademi Manajemen Informatika dan Komputer Aji Jaya Baya di

Gambar. 3. Data Peraturan Kementerian dalam bentuk CSV

\section{2) Preprocessing (Data Cleaning) :}

Tahap ini bertujuan untuk menghilangkan atau mengabaikan kata-kata yang tidak diperlukan untuk menghindari data-data yang tidak berhubungan. Seperti pada data Peraturan Kementerian, kata yang tidak berhubungan dengan hal yang perlu dikelompokkan adalah "Peraturan", "Kementerian", dan lainnya. Pada kode metode K-Means Clustering, data cleaning dilakukan dengan menggunakan 'stopword'. Stopword adalah kata-kata yang tidak diperlukan dan dihilangkan. Berikut adalah stopword yang kami gunakan pada penelitian ini :

Stopword

['2016,',2015','2017','2019','TANAMAN','CARA','TATA','

KEGIATAN','BADAN','KEPUTUSAN','KEPADA','PENC
ABUTAN','KEPALA','PENDIDIKAN','MEDAN','KEPUL AUAN','TOURISM','PEMBUKAAN','JENIS','TAHUN','K EMENTERIAN','MENTERI','PELAKSANAAN','KANDE PDIKBUD','KAMPUNG','KAMBOJA','KALIMANTAN',' MAKASSAR','SURABAYA','TULUNGAGUNG','JOMB ANG','GENDER','SUMATERA','INDONESIA','KANTOR ','NEGARA','NEGERI','DILINDUNGI','SITUS','STUDI',' YOGYAKARTA','SEKOLAH','PERGURUAN','POLITE KNIK','DIPLOMA','ORGANISASI','MENLHK','SETJEN', 'PELAANAAN','NAMA','KPTS','DALAM','KERJA','PER UBAHAN','UNIVERSITAS','PENYELENGGARAAN','P ENYELENGGARA','PELEPASAN','REPUBLIK','KEBU DAYAAN','PEMASUKAN','4A','KABUPATEN','DAERA H','UNDANG','TENTANG','NOMOR','TEMPAT','KAWA SAN','PERATURAN','KEPADA','KEPALA','KOTA','PA 
NDUAN','PEDOMAN','PERENCANAAN','BERENCAN A','MISI','STANDAR','ATAS','MENHUT','SELENGGAR AKAN','PROGRAM','JAKARTA','IZIN','OLEH','TINGGI' ,'YANG','PADA','DAN','DENGAN','MENJADI','DARI','S EBAGAI','DI','KLON','II','III','IV','OT','PIA','MUHAMMA YAH','BIG']

Stopword sendiri dapat diakses di Zenodo [10].

\section{3) Transformation}

Tahap ini bertujuan untuk mentransformasikan data menjadi bentuk yang sesuai untuk diproses dalam data mining. Dalam penelitian ini, transformasi dilakukan dari data yang digunakan diubah menjadi bentuk vektor. Transformasi dilakukan dengan menggunakan kode yang ada di algoritma K-Means Clustering.

\section{4) Data Mining}

Pada tahap data cleaning ini yang dilakukan adalah membuang atribut yang tidak relevan atau tidak konsisten [11]. Tahap ini juga bertujuan untuk mengelompokkan data yang telah ditransformasi ke dalam kelompok-kelompok kecil atau cluster. Cluster data pada penelitian ini menggunakan metode K-Means Clustering. Metode itu merupakan metode cluster data mining menggunakan descriptive model untuk menjelaskan algoritma pengelompokan objek dengan karakteristik yang sama. Perhitungan metode ini dilakukan dengan mengambil $x$ sebagai parameter input, yang masingmasing menjadi pusat dari cluster $x$ [12]. Menurut metode $K$ Means Clustering, pengelompokan bergantung pada pilihan sentroid awal. Elemen data yang digunakan dipilih sebagai sentrois awal lalu semua dihitung dengan rumus Euclidean terhadap sentroid. Elemen data yang memiliki jarak paling kecil ke sentroid dipindahkan ke cluster yang sesuai. Proses tersebut dilakukan berulang hingga tidak ada perubahan lagi pada cluster [13]. Pada penelitian ini Peraturan Kementerian akan dikelompokkan berdasarkan persamaan karakteristik. Pada tahap ini Peraturan Kementerian yang telah diambil, dilakukan data cleaning dan transformasi akan dikelompokkan sesuai dengan kemiripan karakteristik. Hasil pengelompokan dibagi menjadi 2, 3, dan 4 cluster.

Berikut merupakan hasil pengelompokan cluster sesuai dengan persamaan karakteristik kata-kata yang ada di Peraturan Kementerian. Tabel II menunjukkan hasil pengelompokan menjadi dua cluster, Tabel III menunjukkan hasil pengelompokan menjadi tiga cluster, Tabel IV menunjukkan hasil pengelompokan menjadi empat cluster.

TABLE II

PENGELOMPOKAN MENJADI DUA CLUSTER

\begin{tabular}{|c|l|}
\hline Cluster & \multicolumn{1}{|c|}{ Kata } \\
\hline 0 & $\begin{array}{l}\text { PARIWISATA, YAYASAN, KEHUTANAN, } \\
\text { LINGKUNGAN, HIDUP, ILMU, SARJANA, } \\
\text { USAHA, HUTAN, KESEHATAN }\end{array}$ \\
\hline 1 & $\begin{array}{l}\text { VARIETAS, UNGGUL, PERTANIAN, HIBRIDA, } \\
\text { ANAK, PERLINDUNGAN, PEREMPUAN, } \\
\text { PEMBERDAYAAN, BALAI, ANGGARAN }\end{array}$ \\
\hline
\end{tabular}

TABLE III.

PENGELOMPOKAN MENJADI TIGA CLUSTER

\begin{tabular}{|c|c|}
\hline Cluster & Kata \\
\hline$\overline{0}$ & $\begin{array}{l}\text { PARIWISATA, KEHUTANAN, LINGKUNGAN, } \\
\text { ANAK, HIDUP, USAHA, PEREMPUAN, } \\
\text { HUTAN, PERLINDUNGAN, PEMBERDAYAAN }\end{array}$ \\
\hline 1 & $\begin{array}{l}\text { YAYASAN, ILMU, SARJANA, } \\
\text { AKESEHATAN, } \\
\text { PERSYARIKATANOFI, } \\
\text { INFORMATIKA }\end{array}$ \\
\hline 2 & $\begin{array}{l}\text { VARIETAS, UNGGUL, PERTANIAN, HIBRIDA, } \\
\text { BALAI, KARANTINA, HEWAN, PANGAN, } \\
\text { ANGGARAN, BESAR }\end{array}$ \\
\hline
\end{tabular}

TABLE IV.

PENGELOMPOKAN MENJADI EMPAT CLUSTER

\begin{tabular}{|c|l|}
\hline Cluster & \multicolumn{1}{|c|}{ Kata } \\
\hline 0 & $\begin{array}{l}\text { ANAK, PEREMPUAN, PERLINDUNGAN, } \\
\text { PEMBERDAYAAN, LAYAK, KEKERASAN, } \\
\text { KORBAN, RESPONSIF, PENANGANAN, } \\
\text { KEBIJAKAN }\end{array}$ \\
\hline 1 & $\begin{array}{l}\text { VARIETAS, UNGGUL, PERTANIAN, HIBRIDA, } \\
\text { BALAI, ANGGARAN, HEWAN, KARANTINA, } \\
\text { PANGAN, PERKEBUNAN }\end{array}$ \\
\hline 2 & $\begin{array}{l}\text { YAYASAN, ILMU, SARJANA, KESEHATAN, } \\
\text { AKADEMI, PROFESI, TEKNOLOGI, } \\
\text { MANAJEMEN, PERSYRIKATAN, } \\
\text { INFORMATIKA }\end{array}$ \\
\hline 3 & $\begin{array}{l}\text { PARIWISATA, KEHUTANAN, LINGKUNGAN, } \\
\text { EKONOMI, USAHA, HUTAN, WISATA, KREATIF, }\end{array}$ \\
\hline
\end{tabular}

\section{5) Evaluation}

Tahap ini bertujuan untuk menguji kebenaran dari pola kesamaan antar objek yang mewakili knowledge dalam data itu sendiri. Pada penelitian ini, evaluasi dilakukan melalui Elbow Method [14] dengan meminimalkan Sum of Squared Errors (SSE) atau inersia kluster. Metode ini membuat k di tempat SSE mulai mendatar dan membentuk siku. Dari dataset akan mengevaluasi SSE untuk nilai $\mathrm{k}$ yang berbeda dan melihat di mana kurva dapat membentuk siku. Hasil yang paling baik adalah pengelompokan dengan nilai inertia yang paling kecil. Hal ini memperjelas bahwa metode ini akan menghasilkan elbow curve yang berfungsi untuk memvisualisasikan nilai inertia dan menunjukkan pengelompokan cluster terbaik pada dataset [15]. Tabel V. menunjukkan nilai inertia pada setiap pengelompokan cluster dan visualisasi dengan elbow curve ditunjukkan pada Gambar 4.

TABLE V.

NILAI INERTIA PADA SETIAP PENGELOMPOKAN CLUSTER

\begin{tabular}{|c|c|}
\hline $\begin{array}{c}\text { Pengelompokan } \\
\text { X cluster }\end{array}$ & Nilai inertia \\
\hline 2 & 444.98229885730774 \\
\hline 3 & 416.13325979019925 \\
\hline 4 & 405.142786991133 \\
\hline
\end{tabular}




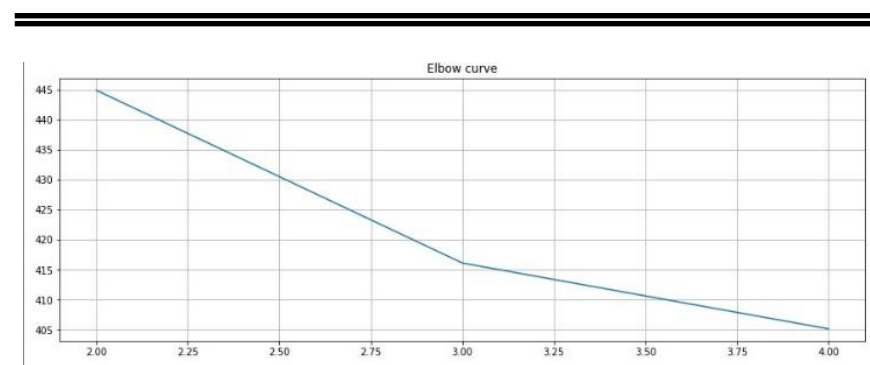

Gambar. 4. Elbow Curve untuk nilai inertia K-Means

\section{6) Knowledge}

Tahap ini bertujuan untuk menyajikan visualisasi data atau informasi hasil dari mining yang dapat digunakan sebagai acuan pengambilan keputusan. Pada penelitian ini, informasi yang dihasilkan adalah fokus permasalahan yang sering dibahas pada Peraturan Kementerian. Berdasarkan hasil analisa yang dilakukan, maka hasil terbaik adalah dengan pengelompokan menjadi empat cluster, dan pengelompokan topik Peraturan Kementerian adalah sebagai berikut :

- Pemberdayaan anak, perempuan, dan korban kekerasan

- Kebijakan lingkungan baik flora dan fauna

- Keilmuan dan keprofesian

- $\quad$ Ekonomi kreatif di bidang pariwisata.

\section{HASIL DAN PEMBAHASAN}

Dari proses yang telah dilakukan, total jumlah data Peraturan Kementerian yang diambil adalah 7233 peraturan. Menimbang dari banyaknya permasalahan yang telah dihadapi oleh Indonesia dimulai dari pemanasan global, penganiayaan terhadap anak dan perempuan, penyalahgunaan sosial/teknologi, pemenuhan mutu dan gizi pangan, pengendalian tata ruang pariwisata [16] menjadikan alasan utama kami untuk hanya mengambil lima situs Peraturan Kemeterian, diantaranya adalah Kementerian Pemberdayaan Perempuan dan Perlindungan Anak, Kementerian Riset dan Teknologi, Kementerian Lingkungan Hidup dan Kehutanan, Kementerian Pertanian, Kementerian Pariwisata. Dari kelima situs tersebut nantinya akan dijadikan bahan pengelompokan atau cluster. Tujuan dari hasil pengemlopokkan atau cluster peraturan tersebut adalah agar pembaca bisa mengetahui peraturan apa saja yang menjadi perhatian dari pemerintah sehingga dari sini bisa timbul solusi untuk pihak terkait agar tatanan di negeri ini menjadi lebih baik lagi. Berikut merupakan jumlah peraturan yang diambil dan digunakan pada penelitian ini dari masing-masing situs yaitu :

TABLE VI.

JUMLAH PERATURAN YANG DIGUNAKAN

\begin{tabular}{|c|l|c|c|}
\hline No & Kementerian & Situs Web & $\begin{array}{c}\text { Jumlah } \\
\text { Peraturan }\end{array}$ \\
\hline 1 & $\begin{array}{l}\text { Kementerian } \\
\text { Pemberdayaan } \\
\text { Perempuan dan } \\
\text { Perlindungan Anak }\end{array}$ & jdih.kemenpppa.go.id & 225 \\
\hline 2 & $\begin{array}{l}\text { Kementerian Riset } \\
\text { dan Teknologi }\end{array}$ & jdih.ristekdikti.go.id & 3510 \\
\hline
\end{tabular}

\begin{tabular}{|c|l|l|c|}
\hline No & \multicolumn{1}{|c|}{ Kementerian } & \multicolumn{1}{c|}{ Situs Web } & $\begin{array}{c}\text { Jumlah } \\
\text { Peraturan }\end{array}$ \\
\hline 3 & $\begin{array}{l}\text { Kementerian } \\
\text { Lingkungan Hidup } \\
\text { dan Kehutanan }\end{array}$ & jdih.menlhk.co.id & 1019 \\
\hline 4 & $\begin{array}{l}\text { Kementerian } \\
\text { Pertanian }\end{array}$ & jdih.pertanian.go.id & 1879 \\
\hline 5 & $\begin{array}{l}\text { Kementerian } \\
\text { Pariwisata }\end{array}$ & jdih.kemenpar.go.id & 600 \\
\hline
\end{tabular}

Berikut merupakan jumlah peraturan yang ada pada masing-masing cluster untuk setiap pengelompokan. Tabel VII. adalah pengelompokan menjadi dua cluster, Tabel VIII. adalah pengelompokan menjadi tiga cluster, dan Tabel IX. adalah pengelompokan menjadi empat cluster.

TABLE VII. JUMLAH PADA PENGELOMPOKAN DUA CLUSTER

\begin{tabular}{|c|c|}
\hline Cluster & Jumlah \\
\hline 0 & 219 \\
\hline 1 & 271 \\
\hline
\end{tabular}

TABLE VIII.

JUMLAH PADA PENGELOMPOKAN TIGA CLUSTER

\begin{tabular}{|c|c|}
\hline Cluster & Jumlah \\
\hline 0 & 283 \\
\hline 1 & 47 \\
\hline 2 & 160 \\
\hline
\end{tabular}

TABLE IX.

JUMLAH PADA PENGELOMPOKAN EMPAT CLUSTER

\begin{tabular}{|c|c|}
\hline Cluster & Jumlah \\
\hline 0 & 43 \\
\hline 1 & 235 \\
\hline 2 & 47 \\
\hline 3 & 165 \\
\hline
\end{tabular}

Dengan hasil clustering terbaik adalah pengelompokan menjadi empat cluster yang memiliki nilai inertia 405.142786991133. Berikut merupakan hasil pengelompokan cluster serta kata-kata yang memiliki karakteristik yang sama pada masing-masing cluster dan topik peraturan yang sering dibahas pada masing-masing cluster dengan pengelompokan terbaik seperti pada Tabel IV.

Cluster 0 menunjukkan bahwa topik Peraturan Kementerian yang menjadi satu cluster adalah mengenai Kebijakan tentang Perlindungan, Pemberdayaan, dan Penanganan Anak, Perempuan dan Korban Kekerasan yang Layak dan Responsif. Cluster 1 menunjukkan bahwa topik Peraturan Kementerian yang menjadi satu cluster adalah mengenai Anggaran dalam bidang Pertanian, Perkebunan, Varietas, Hibrida serta Hewan yang Unggul guna Pemenuhan Kebutuhan Pangan dan bagaimana kebijakan untuk Karantina dan Balai. Cluster 2 menunjukkan bahwa topik Peraturan Kementerian yang menjadi satu cluster adalah mengenai Manajemen Yayasan, Persyarikatan juga profesi perseorangan seperti Sarjana dalam Ilmu dan Profesi dengan Akademi 
tentang Kesehatan, Teknologi, Informatika. Cluster 3 menunjukkan bahwa topik Peraturan Kementerian yang menjadi satu cluster adalah mengenai Jasa Pariwisata yang memanfaatkan Lingkungan Hidup seperti Hutan sebagai Usaha untuk meningkatkan Ekonomi Kreatif.

\section{KESIMPULAN}

Analisis Clustering untuk Peraturan Kementerian menggunakan metode $K$-Means memiliki hasil terbaik dengan pengelompokan cluster menjadi empat cluster yang memiliki nilai inertia 405.142786991133. Dari hasil tersebut, diketahui bahwa dalam pembuatan peraturan kementerian terdapat fokus permasalahan yang sering terjadi. Cluster 0 adalah kumpulan peraturan tentang pemberdayaan anak, perempuan, dan korban kekerasan. Cluster 1 adalah kumpulan peraturan tentang kebijakan lingkungan baik flora dan fauna. Cluster 2 adalah kumpulan peraturan yang berkaitan dengan keilmuan dan keprofesian. Cluster 3 adalah kumpulan peraturan yang berkaitan dengan keselamatan ekonomi kreatif di bidang pariwisata. Dari pengelompokan tersebut, didapatkan fokus permasalahan dalam pembuatan Peraturan Kementerian yang menggambarkan kondisi di Indonesia. Penelitian ini diharapkan bisa menjadi wawasan dan ilmu baru untuk penelitian-penelitian selanjutnya.

\section{ACKNOWLEDGMENT}

Penelitian ini didukung oleh Institut Teknologi Sepuluh Nopember. Kami berterima kasih kepada Tuhan Yang Maha Esa dan juga kepada Ibu Nur Aini Rakhmawati, S.Kom., M.Sc.Eng., Ph.D atas arahan dan bimbingannya yang mempengaruhi terhadap hasil penelitian ini.

\section{DAFTAR PUSTAKA}

[1] A. Budiarti dan S. Wahyuni, "HUBUNGAN TINGKAT PENERAPAN PERATURAN, LINGKUNGAN DAN FASILITAS DENGAN KONDISI BELAJAR DI ASRAMA AKBID WIRA HUSADA NUSANTARA MALANG," BIOMED SCIENCE, vol. 5, pp. 1-6, 2017.

[2] R. SARASWATI, "INDONESIA, PERKEMBANGAN PENGATURAN SUMBER HUKUM DAN TATA URUTAN PERATURAN PERUNDANG-UNDANGAN DI," pp. 48-59, 28 Jan 2010.
[3] M. Siahaan, "Uji Konstitusionalitas Peraturan Perundang-Undangan Negara Kita: Masalah dan Tantangan," Jurnal Konstitusi, vol. 7, 2016.

[4] N. I. Febianto dan N. D. Palasara, "Analisis Clustering K-Means Pada Data Informasi Kemiskinan Di Jawa Barat Tahun 2018," SISFOKOM, vol. 8, 2019

[5] S. Khanmohammadi, N. Adibeig dan S. Shanehbandy, "An improved overlapping k-means clustering method for medical applications," Expert Systems With Applications, vol. 67, pp. 12-18, 2016.

[6] P. Sari, B. Pramono dan L. O. H. S. Sagala, "IMPROVE K-MEANS TERHADAP STATUS NILAI GIZI PADA BALITA," semanTIK, vol. 3, pp. 143-148, 2017.

[7] Jamal dan D. Yanto, "Analisis RFMdan Algoritma K-Means untuk Clustering Loyalitas Customer," Jurnal ENERGY, vol. 9, 2019.

[8] Y. She dan L. Zhang, "Study on Liver Visceral Manifestation of Huangdi's Internal Classic of," dalam International Conference on Economics, Business, Management and Corporate Social Responsibility, 2018.

[9] INFORMATIKALOGI, “Algoritma K-Means Clustering,” 12 November 2016. [Online]. Available: https://informatikalogi.com/algoritma-k-means-clustering/. [Diakses 26 February 2020].

[10] G. R. Styawan, A. A. Rayhan, R. A. Putri, N. I. Maghfirani dan N. A. Rakhmawati, "K-Means Clustering Peraturan Kementerian," 8 March 2020. [Online]. Available: http://doi.org/10.5281/zenodo.3700738. [Diakses 8 March 2020].

[11] Gustientiedina, M. H. Adiya dan Y. Desnelita, "Penerapan Algoritma K-Means Untuk Clustering Data Obat-Obatan Pada RSUD Pekanbaru," Jurnal Nasional Teknologi dan SIstem Informasi, vol. 5, pp. 017-024, 2019.

[12] A. Jamal, A. Handayani, A. A. Septiandri, E. Ripmiatin dan Y. Effendi, "Dimensionality Reduction using PCA and K-Means Clustering for Breast Cancer Prediction," Jurnal Ilmiah Teknologi Informasi, vol. 9, 2018.

[13] U. R. Raval dan C. Jani, "Implementing \& Improvisation of K-means Clustering Algorithm," International Journal of Computer Science and Mobile Computing, vol. 5, no. 5, pp. 191-203, 2016.

[14] Towards Data Science, "K-means Clustering: Algorithm, Applications, Evaluation Methods, and Drawbacks," 18 September 2018. [Online]. Available: https://towardsdatascience.com/k-meansclustering-algorithm-applications-evaluation-methods-and-drawbacksaa03e644b48a. [Diakses 8 March 2020].

[15] L. Li, "towards data science," 31 May 2019. [Online]. Available: https://towardsdatascience.com/k-means-clustering-with-scikit-learn6b47a369a83c. [Diakses 8 March 2020].

[16] "Indonesia - World Report 2019: Indonesia," Human Rights Watch, [Online]. Available: https://www.hrw.org/world-report/2019/countrychapters/indonesia. [Diakses 13 April 2020]. 